\title{
GROWTH PERFORMANCE, NUTRIENT RETENTION, SERUM BIOCHEMICAL INDICES AND CARCASS CHARACTERISTICS OF BROILER FINISHER BIRDS SERVED ALOE VERA GEL EXTRACT SUPPLEMENT
}

\author{
Edeh Henry Onyeji ${ }^{1 *}$, Ani Augustine Ogbonna ${ }^{1}$, Osita Charles Onochie ${ }^{1}$, \\ Ogwuegbu Mercy Chisara ${ }^{1}$ and Ilo Stanley Uzochukwu ${ }^{1}$ \\ ${ }^{1}$ Department of Animal Science, University of Nigeria Nsukka 410001, Nigeria \\ *Corresponding author
}

DOI: https://doi.org/10.51193/IJAER.2021.7103

\begin{abstract}
The use of commercially produced vitamins is costly and tends to increase the cost of poultry production. In view of this, there is increased interest to search for leaves of medicinal plants that can serve as natural sources of vitamins and minerals. The use of aloe vera leaf extract is a step in the right direction, since it is a potential source of these essential nutrients. Hence a 4-week study was conducted to investigate the oral supplementation of aloe vera gel extract (AVGE) on growth performance, nutrient retention, serum biochemical indices and carcass characteristics of broiler finisher using one hundred and twenty 4 weeks old broiler birds. The birds were randomly divided into five groups and assigned to five treatments of 24 birds each in a completely randomized design (CRD). Each treatment was replicated three times with 8 birds per replicate. Birds on treatments 1, 2, 3, 4, and 5 received ordinary water, Vitaltye, $10 \%, 20 \%$, and $30 \%$ aqueous AVGE, respectively. Results showed that AVGE had significant $(\mathrm{p}<0.05)$ effects on final body weight, feed conversion ratio and cost of feed per kilogram gain. Treatments had significant $(p<0.05)$ effects on all the nutrient retentions parameters determined. The results showed significant $(\mathrm{p}<0.05)$ differences in all the serum biochemical indices determined. Finally, there were significant $(\mathrm{p}<0.05)$ effect in all the carcass and relative organ weight measured. Based on the results in this study, it was concluded that AVGE supplement to broiler finishers enhanced their growth performance, especially at the $30 \%$ inclusion level.
\end{abstract}

Keywords: aloe vera gel extract, broiler finishers, nutrient retention, growth performance, carcass quality. 
International Journal of Agriculture and Environmental Research

ISSN: 2455-6939

Volume: 07, Issue: 01 "January-February 2021"

\section{INTRODUCTION}

Poultry production has been described as one of the fastest means of achieving appreciable improvement in the nutritional standard of the Nigeria populace because of its short generation interval, quick turnover rate and relatively low capital investment (1); (2). However, to achieve maximum health and performance of poultry, birds must be supplied with adequate and nutritionally balanced diets. Besides, one of the common issues with regard to back yard flocks relates to poor or inadequate feeding programs that can lead to vitamin and mineral deficiencies in the birds. Vitamin and mineral deficiencies can produce numerous health problems for chickens including death in some cases. Thus, to prevent nutritional deficiencies, or to correct when deficiency symptoms are noted, feeding a balanced poultry ration with the required vitamins and minerals should be practiced. Moreover, oral administration of vitamins and minerals to birds is inevitable especially in the time of stress and outbreak of diseases. The use of commercially produced vitamins is costly and tends to increase the cost of poultry production. In view of this, there is increased interest by poultry farmers to search for leaves of ethno medicinal plants that can serve as natural sources of vitamins and minerals. The use of various plant extracts in broiler production has been recorded (3); (4); (5);(6). One of such plant extracts is Aloe vera (Aloe barbadensis) which belongs to the lily family. Aloe vera contains numerous vitamins: Vitamin A, C, and D (are crucial antioxidants that combat free radicals in the body); Vitamin B and choline are concerned with the production of energy, amino acid metabolism developing muscle mass. Vitamin B12 (folic acid) is responsible for the production of red blood cells (7). The use of aloe vera leaf extract in broiler production is a step in the right direction, since it is a potential source of these essential nutrients that are necessary for normal well being, growth and development of birds (8); (9); (10). This study was therefore conducted to evaluate the growth performance, serum biochemical indices, nutrient retention and carcass characteristics of broiler finisher birds served aloe vera gel extract supplement.

\section{MATERIALS AND METHODS}

Ethical Consideration: The experiment was carried out by the provisions of the Ethical Committee on the use of animals and humans for biomedical research of the University of Nigeria, Nsukka.

Study Site: The study was carried out at the Poultry Unit of the Department of Animal Science Teaching and Research Farm, University of Nigeria, Nsukka. Nsukka lies within longitude $6^{\circ}$ $45^{\prime} \mathrm{E}$ and $7^{\circ} \mathrm{E}$ and latitude $7^{\circ} 12.5^{\prime} \mathrm{N}$ and on the altitude $447 \mathrm{~m}$ above sea level. The climate of the study area is typically tropical, with relative humidity ranging from 65 to $80 \%$ and mean daily temperature of $26.8^{\circ} \mathrm{C}(11)$. 
The study lasted for a period of four weeks.

\section{Preparation of Aloe Vera Gel Extract}

Fresh aloe vera leaves were collected from Mbu town in Isi-uzo Local Government Area of Enugu State. The leaves were washed with clean water to remove dirt. Aloe vera gel was extracted manually from leaves by making a cut on the leaves with a pocket knife. The gel was scooped out with a small spoon and drained into a beaker. The extract was prepared by pouring $400 \mathrm{ml}$ (0.4litre) of fresh gel into a glass bottle containing 1.5 litre of clean tap water. The bottle was agitated for about 2 minutes to ensure thorough mixing, after which it was kept for 30 minutes at room temperature prior to use. The homogenized aloe vera gel extract (AVGE) was prepared at the interval of two (2) days and served to the animals fresh according to the treatments.

\section{Experimental Birds and Management}

One hundred and twenty 4 weeks old male and female broiler birds were used for the study. The birds were randomly allotted to five treatment groups of 24 birds each in a completely randomized design $(\mathrm{CRD})$. The treatments were as follows: $\mathrm{T} 1=$ water; $\mathrm{T} 2=$ (vitalyte +4 liters of water $) ; \mathrm{T} 3=(0.4$ litre of AVGE + 4litres of water $) ; \mathrm{T} 4=(0.8$ litre of AVGE+4 litres of water $)$ and $\mathrm{T} 5=(1.2$ litre of AVGE +4 litres of water). Treatment 1 served as the control while T2 was commercial vitalyte which contained vitamins supplement. Each treatment was replicated three times with 8 birds per replicate placed in a deep litter pen of fresh wood shavings measuring $1.50 \mathrm{~m} \times 1.50 \mathrm{~m}$. All the groups were fed the same commercial broiler finisher diet containing $2.89 \mathrm{Mcal} / \mathrm{kg} \mathrm{ME}, 18.56 \%$ crude protein and $5.85 \%$ crude fibre. Routine management practices in terms of medication and vaccination were strictly observed. The test material which was AVGE was added in the drinking water according to the treatments and served ad libitum to the birds for the four weeks experimental period.

\section{Data collection}

The experimental feed, AVGE, water and vitalyte were given ad libitum to the birds for the four weeks experimental period. Birds in each replicate were weighed at the beginning of the experiment and subsequently on weekly basis to determine the weight gain of birds. Feed intake was recorded daily and was determined by the weigh-back technique, and this involved obtaining the difference between quantity of feed offered and the left over the following morning. Feed conversion ratio was calculated from the data on feed intake and weight gain as the number of grams of feed consumed per gram of weight gained over the same period.

\section{Apparent nutrient retention determination.}


At week 4 of the experiment, apparent nutrient retention was determined. The birds were housed individually in metabolism cages. Feed was offered at $90 \%$ of the average daily feed intake to ensure that it was all consumed and to minimize wastage (12). The birds were allowed for two days to adjust to the cage environment before data collection. Daily feed consumption was recorded as the difference between the quantity offered and the quantity left after 24 hours. Faecal droppings were collected from separate cages in detachable trays placed beneath the wire mesh floor of the cages, oven-dried at $60^{\circ} \mathrm{C}$ and weighed over a seven day period. At the end of the period, all faecal samples from each bird were bulked and preserved for analysis. The samples were later analyzed for proximate composition according to the methods of AOAC (13).

\section{Apparent Nutrient Retention $=\underline{\text { Nutrient intake }- \text { Nutrient in Feases }}$ X 100}

Nutrient intake

\section{Serum biochemical analysis}

At the $4^{\text {th }}$ week of the experiment, three birds per treatment were randomly selected and blood samples were collected from the wing veins of each bird using sterilized syringe and emptied into sterilized plain bottles. Serum metabolites (total protein (TP), glucose albumin, globulin, creatinine, cholesterol and calcium) were determined according to the methods described by Campbell and Coles (14).

\section{Carcass and organ evaluation}

At the end of the four weeks experimental period, three birds per treatment were randomly selected, starved overnight and weighed for carcass and organ evaluation. The birds were slaughtered by severing the jugular vein, scalded in warm water for a minute and de-feathered by manual plucking. The birds were eviscerated and weighed to obtain their dressed carcass weight. The kidneys, liver, gizzard, heart, intestine, lungs, head and legs were removed and weighed using a sensitive scale. The kidneys, liver, heart, intestine and lungs were grossly examined for any pathological lesion. The dressed carcass weight and the organ weights were expressed as percentages of live weight.

\section{Proximate and Statistical Analyses}

The aloe vera gel extract was assayed for proximate composition by the method of AOAC (13). Data collected were subjected to analysis of variance (ANOVA) for completely randomized design (CRD) using a statistics package for social sciences (15) Model. Significantly different means were separated using Duncan's New Multiple Range Test (16) 
International Journal of Agriculture and Environmental Research

ISSN: 2455-6939

Volume: 07, Issue: 01 "January-February 2021"

\section{RESULTS AND DISCUSSION}

The proximate composition of Aloe vera gel is presented in table 1.

Table 1: Proximate composition of Aloe vera gel extract

\begin{tabular}{ll}
\hline Components & AVGE \\
\hline Dry matter (\%) & 44.06 \\
Crude fibre (\%) & 10.00 \\
Ether extract (\%) & 4.40 \\
Crude protein (\%) & 20.02 \\
Ash (\%) & 8.99 \\
Nitrogen-free extract (\%) & 0.65 \\
\hline
\end{tabular}

The crude protein value $(20.02 \%)$ obtained in the present study is higher than the crude protein value of $6.86 \%$ reported by (10). However, the crude fibre and ash values $(10.00 \%$ and $8.99 \%$, respectively) obtained in the present study were lower than crude fibre and ash values $(13.35 \%$, and $16.88 \%$, respectively) reported by (10). The proximate values obtained in the present study were also higher than the values (moisture, 11.7\%; ether extract, 2.91\%; ash, 2.36\%; crude protein, $4.73 \%$ and crude fibre, $7.84 \%$ ) reported by (17). The observed differences, especially in the crude protein and crude fibre contents may be due to differences in geographical locations, age and varieties/cultivars of the leaves evaluated in the different studies. It is well known fact that as leaves advance in age, the crude protein reduces whereas the crude fibre content increases (18).

\section{Effect of aqueous aloe vera gel extracts on growth performance of broiler finisher birds}

The effect of aqueous aloe vera gel extract on growth performance of broiler finishers is presented in Table 2.

There were no significant $(\mathrm{p}>0.05)$ differences among treatments in average daily weight gain (ADWG), average daily feed intake, average daily water intake and protein efficiency ratio. There were significant $(\mathrm{p}<0.05)$ differences among treatments in final body weight $(\mathrm{FBW})$, feed conversion ratio (FCR), cost of feed per kilogram gain (CFG), and mortality rate. The FBW values of T4 $(3.38 \mathrm{~kg})$ and T5 $(3.41 \mathrm{~kg})$ were significantly $(\mathrm{p}<0.05)$ higher than the final body weight $(\mathrm{FBW})$ values of $\mathrm{T} 1(3.15 \mathrm{~kg})$ and T2 $(3.15 \mathrm{~kg}) . \mathrm{T} 3, \mathrm{~T} 4$ and T5 were statistically similar ( $\mathrm{p}>0.05$ ) so also T1, T2 and T3. The feed conversion ratio (FCR) values of T4 (3.28) and T5 (3.26) were significantly ( $\mathrm{p}>0.05)$ smaller than other treatments. T3 (3.33) had lower FCR than 
International Journal of Agriculture and Environmental Research

ISSN: 2455-6939

Volume: 07, Issue: 01 "January-February 2021"

$\mathrm{T} 1$ (3.46) and $\mathrm{T} 2$ (3.52). The cost of feed/kg gain values of $\mathrm{T} 1$ and $\mathrm{T} 2$ were significantly (p < 0.05) higher than AVGE groups.

Table 2: Effect of aqueous alovera gel extracts on growth performance of finisher broiler birds:

\begin{tabular}{|c|c|c|c|c|c|c|}
\hline Trea & ments* & & & & & \\
\hline Parameters & $\mathrm{T} 1$ & $\mathrm{~T} 2$ & T3 & $\mathrm{T} 4$ & T5 & SEM \\
\hline Initial body weight(g) & 1268.00 & 1270.00 & 1265.00 & 1267.00 & 1269.00 & 2.31 \\
\hline Final Body weight (kg) & $3.15^{\mathrm{b}}$ & $3.15^{\mathrm{b}}$ & $3.28^{\mathrm{ab}}$ & $3.38^{\mathrm{a}}$ & $3.41^{\mathrm{a}}$ & 0.04 \\
\hline Daily weight gain $(\mathrm{g}) / \mathrm{bird}$ & 50.00 & 50.00 & 51.02 & 51.70 & 52.05 & 0.07 \\
\hline $\begin{array}{l}\text { Average daily feed } \\
\text { intake(g)/bird }\end{array}$ & 173.00 & 176.00 & 170.00 & 170.00 & 170.00 & 0.01 \\
\hline Feed conversion ratio & $3.46^{\mathrm{a}}$ & $3.52^{\mathrm{a}}$ & $3.33^{\mathrm{b}}$ & $3.28^{c}$ & $3.26^{\mathrm{c}}$ & 0.05 \\
\hline Daily water intake(cl)/bird & 70.00 & 69.70 & 70.70 & 70.00 & 70.60 & 0.30 \\
\hline $\begin{array}{l}\text { Protein efficiency } \\
\text { ratio(PER) }\end{array}$ & 1.59 & 1.59 & 1.59 & 1.59 & 1.59 & 0.00 \\
\hline Cost of $1 \mathrm{~kg}$ of feed( & 130.00 & 130.00 & 130.00 & 130.00 & 130.00 & 0.00 \\
\hline Cost of feed per kg gain( $(\mathrm{N})$ & $449.8^{\mathrm{a}}$ & $457.6^{\mathrm{a}}$ & $432.9^{b}$ & $426.4^{\mathrm{c}}$ & $423.8^{c}$ & 4.50 \\
\hline
\end{tabular}

Means on the same row with different superscripts are significantly $(\mathrm{P}<0.05)$ different.

$\mathrm{SEM}=$ Standard Error of the Mean.

*T1 $=$ water; $\mathrm{T} 2=$ vitalyte T3 $=(0.4$ litre of AVGE +4 litre of water $) ; \mathrm{T} 4=(0.8$ litre of AVGE +4 litre of water) and $\mathrm{T} 5=(1.2$ litre of AVGE +4 litre of water $)$.

The higher body weight gain and improved FCR values observed in this findings with the birds on aloe vera groups, T3, T4 and T5 supports findings done by (19) using $10 \mathrm{ml}$ of aqueous extract of aloe gel per liter of drinking water. (20) also reported that Aloe vera gel added to water resulted in significant increase in final body weight gain as well as in weekly body weight gain compared to control group. This could be due to the fact that aloe vera possesses diversified antimicrobial nutrients, minerals, vitamins, enzymes and glycoproteins (21) and these might have helped the birds in better digestions and absorptions of nutrients than birds on control group. Vitamins boost immune systems while enzymes help to breakdown food and assist in digestion of food. The result of the present study was also consistent with the findings of (22) who reported that higher body weight were observed in the groups of broilers that received dietary 
International Journal of Agriculture and Environmental Research

ISSN: 2455-6939

Volume: 07, Issue: 01 "January-February 2021"

inclusion of Aloe vera and Curcuma longa. (9) and (23) found similar result that aloe vera increased body weight of cockrel at 5\% and in broiler at $0.5 \%$ inclusions level. However, this finding disagrees consistently with (24) who reported that broiler chickens fed with fresh Aloe vera gel $(0.25 \mathrm{~g} / \mathrm{kg})$ and dry Aloe vera gel $(0.25$ and $1.0 \mathrm{~g} / \mathrm{kg})$ had no significant effect on body weight. The non significant $(\mathrm{P}<0.05)$ effect noticed in total water intake of the birds supports the report of (25) who reported no significant difference in mean water intake among broiler birds. (26) reported similar findings whereas; (27) and (19) reported higher water intake in aloe vera groups than antibiotic group. It could also be attributed that the birds got adapted to bitter taste of aloe vera gel extracts. The aloe vera groups and $\mathrm{T} 2$ were statistically similar with the control group in protein efficiency ratio. This was in contrary with (28); (22) that noticed improved protein efficiency in aloe vera powder and gel treated groups as compared to control group.

The significant decrease in feed cost $/ \mathrm{kg}$ gain in aloe vera groups showed that farmers stand better chance of making profit than using the commercial vitalyte to produce $1 \mathrm{~kg}$ of a bird. This is in support of (9) that reported higher profit in using aloe vera to feed cockerel.

\section{Effect of aqueous aloe vera gel extracts on apparent nutrient retention of broiler finisher birds}

The effect of aqueous aloe vera gel extract on apparent nutrient retention of broiler finisher birds is presented in Table 3 . There were significant $(\mathrm{p}<0.05)$ differences among treatments in all the parameters determined with the exception of dry matter retained. The values of crude protein retained $(\mathrm{CPR})$ of $\mathrm{T} 2, \mathrm{~T} 3, \mathrm{~T} 4$ and $\mathrm{T} 5$ were significantly $(\mathrm{p}<0.05)$ higher than the $(\mathrm{CPR})$ value of T1. The results of this findings showed that $\mathrm{T} 4$ and $\mathrm{T} 5$ retained more crude fibre than other groups. T1 and T2 were significantly $(\mathrm{p}<0.05)$ lower in ether extract retained than AVGE groups. T3 had lower percentage value of ether extract retained compared to other AVGE groups (T4 and T5). It was observed from this finding that $\mathrm{T} 1$ and $\mathrm{T} 2$ were significantly $(\mathrm{p}<0.05)$ higher than aloe vera groups (T3, T4 and T5) in percentage values of ether extract retained (EER). 
International Journal of Agriculture and Environmental Research

ISSN: 2455-6939

Volume: 07, Issue: 01 "January-February 2021"

\begin{abstract}
Table 3: Effect of aqueous aloe vera gel extract on apparent nutrient retention of broiler finisher birds
\end{abstract}

\begin{tabular}{lllllll}
\hline & \multicolumn{7}{c}{ Treatments* } \\
\hline Parameters & T1 & T2 & T3 & T4 & T5 & SEM \\
\hline Crude protein retained (\%) & $80.91^{\mathrm{b}}$ & $91.15^{\mathrm{a}}$ & $91.20^{\mathrm{a}}$ & $91.88^{\mathrm{a}}$ & $88.93^{\mathrm{a}}$ & 1.26 \\
Crude fibre retained (\%) & $22.09^{\mathrm{b}}$ & $34.65^{\mathrm{b}}$ & $32.39^{\mathrm{b}}$ & $38.09^{\mathrm{a}}$ & $36.70^{\mathrm{a}}$ & 2.45 \\
Dry matter retained (\%) & 63.15 & 66.10 & 63.15 & 65.07 & 62.01 & 1.17 \\
Ether extract retained (\%) & $84.64^{\mathrm{c}}$ & $86.94^{\mathrm{c}}$ & $92.813^{\mathrm{b}}$ & $95.86^{\mathrm{a}}$ & $90.29^{\mathrm{b}}$ & 1.13 \\
Nitrogen-free extract retained & $78.35^{\mathrm{a}}$ & $76.72^{\mathrm{a}}$ & $63.52^{\mathrm{b}}$ & $63.24^{\mathrm{b}}$ & $64.25^{\mathrm{b}}$ & 2.15 \\
& & & & & & \\
\hline
\end{tabular}

a,b,c Means on the same row with different superscripts are significantly $(\mathrm{P}<0.05)$ different.SEM= Standard Error of the Mean.

The improved crude protein (CP) retention of birds on the vitalyte and aloe vera groups could be attributed to the antimicrobial; appetite- and digestion-stimulating properties in some plant extracts, including aloe vera extract (29). This also supports the high crude fibre value of T4 and T5. Although birds on treatments 1 and 2 (water and vitalyte) retained more nitrogen-free extract than other birds, their overall performances were not superior to those of birds on treatments containing aloe vera extract. This tends to suggest that the inclusion of aloe vera extract in the birds' drinking water had a beneficial effect on the birds. This agreed with (30) who reported that herbs can stimulate appetite and endogenous secretions which, in turn, improve performance. He stated that beneficial effects of herbal extracts on farm animals may be as a result of the increase in feed intake and activation of digestive enzymes secretion of the animals, emanating from the immune stimulating, and anti-bacterial, anti-viral and anti-oxidant properties of these extracts.

\title{
Effect of aqueous aloe vera gel extract on biochemical parameters of broiler finisher birds
}

The effect of aqueous aloe vera extract on biochemical parameters of broiler finisher birds is presented in Table 4.

The effects of aloe vera gel extract were noticed in all serum biochemistry indices determined. The total protein (TP) values of T1 (3.67) and T5 (3.77) were significantly ( $<0.05)$ higher than total protein values of T2 and T3 but statistically similar $(\mathrm{p}>0.05)$ to TP value of T4. The total protein values of $\mathrm{T} 2, \mathrm{~T} 3$ and $\mathrm{T} 4$ were statistically similar $(\mathrm{p}>0.05)$. Aloe vera gel decreased the 
International Journal of Agriculture and Environmental Research

ISSN: 2455-6939

Volume: 07, Issue: 01 "January-February 2021"

albumin value of T4 (1.53) and this was significantly $(\mathrm{p}<0.05)$ lower than the albumin (ALB) value of other treatments. The effect of AVGE on T2 and T3 showed a decrease in globulin (GLB) value than T1, T4 and T5 GLB values. The glucose (GLU) value of T1 (147.33) and T2 (127.30) showed significant ( $p>0.05$ ) increase compared to AVGE (103.33, 100.67 and 98.67) groups. The results showed that AVGE lowered glucose level. The creatinine value of T5 (0.29) was statistically $(\mathrm{p}<0.05)$ higher than creatinine values of other treatments. T2 (74.99) had a lower value of cholesterol than other treatments. The effect of AVGE on T5 (7.53) showed a $(p<0.05)$ higher calcium value than the rest of other treatments.

\section{Table 4: Effects of aqueous alovera gel extract on Serum biochemical indices of broiler finisher birds.}

\begin{tabular}{lllllll}
\hline \multicolumn{7}{c}{ Treatments* } \\
\hline Parameters & T1 & T2 & T3 & T4 & T5 & SEM \\
\hline Total protein(g/dl) & $3.67^{\mathrm{a}}$ & $3.03^{\mathrm{b}}$ & $3.03^{\mathrm{b}}$ & $3.20^{\mathrm{ab}}$ & $3.77^{\mathrm{a}}$ & 0.11 \\
Albumin $(\mathrm{g} / \mathrm{dl})$ & $1.97^{\mathrm{a}}$ & $2.23^{\mathrm{a}}$ & $2.23^{\mathrm{a}}$ & $1.53^{\mathrm{b}}$ & $2.17^{\mathrm{a}}$ & 0.14 \\
Globulin $(\mathrm{g} / \mathrm{dl})$ & $1.70^{\mathrm{a}}$ & $0.80^{\mathrm{b}}$ & $0.80^{\mathrm{b}}$ & $1.67^{\mathrm{a}}$ & $1.60^{\mathrm{a}}$ & 0.16 \\
Glucose $(\mathrm{mg} / \mathrm{dl})$ & $147.33^{\mathrm{a}}$ & $127.30^{\mathrm{b}}$ & $103.33^{\mathrm{c}}$ & $100.67^{\mathrm{c}}$ & $98.67^{\mathrm{c}}$ & 8.03 \\
Creatine $(\mathrm{mg} / \mathrm{dl})$ & $0.06^{\mathrm{b}}$ & $0.06^{\mathrm{b}}$ & $0.06^{\mathrm{b}}$ & $0.08^{\mathrm{b}}$ & $0.29^{\mathrm{a}}$ & 0.04 \\
Cholesterol(mg/dl) & $109.00^{\mathrm{a}}$ & $74.99^{\mathrm{b}}$ & $108.33^{\mathrm{a}}$ & $117.00^{\mathrm{a}}$ & $120.00^{\mathrm{a}}$ & 8.10 \\
Calcium $(\mathrm{mg} / \mathrm{dl})$ & $6.73^{\mathrm{b}}$ & $6.90^{\mathrm{b}}$ & $6.83^{\mathrm{b}}$ & $6.97^{\mathrm{b}}$ & $7.53^{\mathrm{a}}$ & 0.13 \\
\hline
\end{tabular}

a,b,c Means on the same row with different superscripts are significantly $(\mathrm{P}<0.05)$ different. $\mathrm{SEM}=$ Standard Error of the Mean.

This finding did not support (8) who reported that dietary inclusion of aloe vera and curcuma longa and its combinations in broiler birds has no significant effect on the treated groups. The significant increase in serum creatinine in treatment 5 is in agreement with; (31) and (32) who reported significant increase in serum creatinine and urea levels when aloe vera was added to the diet of broilers. This study revealed that aloe induces a significant rise in serum creatinine when 1.2 liters of AVGE was added in 4 litres of water. This is in consonance with the study of (33) and (34) that reported the cytotoxic effect of aloe and high creatinine in aloe vera treated rat. Reduced protein level in T3 and albumin levels in T4 is in agreement with the report of (22) that reported decreased in albumin value in broiler birds treated with aloe vera and tumeric. It was also observed in this study that AVGE groups had lower glucose values compared to the control groups T1 (water) and T2 (vitalyte). This was in agreement with (35) who stated that the oral administration of aloe vera gel extract $(300 \mathrm{mg} / \mathrm{kg}$ body weight per day) to streptozotocin 
International Journal of Agriculture and Environmental Research

ISSN: 2455-6939

Volume: 07, Issue: 01 "January-February 2021"

induced diabetic rats had a significant reduction in fasting glucose. Similar studies indicate that Aloe vera extract is effective in increasing insulin sensitivity, reducing fasting blood glucose, and decreasing the level of $\mathrm{HbA1C}$ in patients with pre-diabetes during eight weeks (36). Other studies have also shown the effectiveness of Aloe vera extract on the regulation of blood glucose levels in diabetic animals (37); (39). According to (38), aloe vera decreases blood sugar level in hyperglycemic patients. This study did not support few studies that indicated a rise in blood sugar levels after consumption of Aloe vera extract (39). These might be related to the use of different parts of the plant (not the gel) or short duration of administration. (40) and (41) reported that, Aloe vera also contains other compounds such as hydrophilic fiber, glucomannan and phytosterol that reduce blood glucose. The effect of AVGE on calcium value in this study supports (42) that recorded up to $9.08 \mathrm{mg} / \mathrm{dl}$ in broiler birds treated with aloe vera. The significant increase observed in the calcium level in this study may be attributed to the calcium content of aloe vera. It has been reported that among the important minerals found in aloe vera are: calcium, chromium, copper, iron, magnesium, manganese, potassium, phosphorous, sodium, and zinc (7).

\section{Effects of aqueous aloe vera gel extract on carcass and relative organ weights of broiler finishers}

The Effects of aqueous aloe vera gel extract on carcass and relative organ weights of broiler finishers is presented in Table 5

There were significant $(\mathrm{p}<0.05)$ differences among treatments in all the parameters. The results showed that $\mathrm{T} 1, \mathrm{~T} 2$ and $\mathrm{T} 4$ were significantly $(\mathrm{p}<0.05)$ higher in live body weight than $\mathrm{T} 3$ and T5 live weight. The percentage dressed weight of T3 was significantly $(\mathrm{p}<0.05)$ lower than percentage dressed weights of T1, T2 and T4 but statistically similar with T5. Aloe vera gel extract (AVGE) had an increase effect on relative head weight than T2 but were statistically similar ( $p>0.05)$ in relative head weight value of $\mathrm{T} 1$. The finding revealed that the relative gizzard weight and empty gizzard weight of T3 and T4 were significantly $(\mathrm{p}<0.05)$ higher than other treatments. The relative shank weight of $\mathrm{T} 2$ was smaller than other shank weight while $\mathrm{T} 4$ had the highest value for relative shank weight. The percentage heart weight of T4 $(0.76 \%)$ was statistically $(\mathrm{p}<0.05)$ higher than the percentage height weight of other treatments. There was high value of relative liver weight of T5 (1.90) compared to other group but showed statistical similar value with T1 (1.78). The effect of AVGE on T5 showed a significant $(\mathrm{p}<0.05)$ higher weight of kidney than other treatments. The abdominal fat deposition of T2 was significantly $(\mathrm{p}<0.05)$ higher than the abdominal value of the control (T1) and that of the AVGE groups. The birds on T4 and T5 had higher values of relative lung weight and relative small intestine weight compared to T1, T2 and T3 respectively. The result of this finding showed that there was 
increase in weight of large intestine weight of birds that were administered AVGE than T1 and $\mathrm{T} 2$ that received ordinary water and commercial vitalyte.

Table 5: Effects of aqueous alovera gel extract on carcass and relative organ weights of broiler finishers.

\begin{tabular}{|c|c|c|c|c|c|c|}
\hline & \multicolumn{6}{|c|}{ Treatments* } \\
\hline Parameters & $\mathrm{T} 1$ & $\mathrm{~T} 2$ & T3 & $\mathrm{T} 4$ & T5 & SEM \\
\hline Live weight(kg) & $3.80^{\mathrm{a}}$ & $3.73^{\mathrm{a}}$ & $3.60^{\mathrm{a}}$ & $3.53^{\mathrm{a}}$ & $3.27^{\mathrm{b}}$ & 0.09 \\
\hline $\begin{array}{l}\text { Dressed weight } \\
(\%)\end{array}$ & $77.82^{\mathrm{a}}$ & $77.10^{\mathrm{a}}$ & $68.71^{\mathrm{b}}$ & $70.14^{\mathrm{ab}}$ & $74.13^{\mathrm{ab}}$ & 1.39 \\
\hline $\begin{array}{l}\text { Head weight } \\
(\%)\end{array}$ & $1.07^{\mathrm{ab}}$ & $1.81^{b}$ & $2.36^{\mathrm{a}}$ & $2.15^{\mathrm{a}}$ & $2.18^{a}$ & 0.07 \\
\hline $\begin{array}{l}\text { Gizzard weight } \\
(\%)\end{array}$ & $2.30^{\mathrm{b}}$ & $2.35^{\mathrm{b}}$ & $2.69^{\mathrm{ab}}$ & $2.88^{\mathrm{a}}$ & $2.55^{\mathrm{b}}$ & 0.10 \\
\hline $\begin{array}{l}\text { Empty gizzard } \\
\text { weight }(\%)\end{array}$ & $1.72^{b}$ & $1.68^{b}$ & $1.92^{\mathrm{a}}$ & $2.06^{\mathrm{a}}$ & $1.79^{\mathrm{b}}$ & 0.07 \\
\hline $\begin{array}{l}\text { Shank weight } \\
(\%)\end{array}$ & $3.26^{\mathrm{b}}$ & $2.93^{c}$ & $3.33^{b}$ & $3.71^{\mathrm{a}}$ & $3.28^{b}$ & 0.12 \\
\hline $\begin{array}{l}\text { Heart weight } \\
(\%)\end{array}$ & $0.42^{b}$ & $0.42^{b}$ & $0.41^{b}$ & $0.76^{\mathrm{a}}$ & $0.41^{b}$ & 0.06 \\
\hline $\begin{array}{l}\text { Liver weight } \\
(\%)\end{array}$ & $1.78^{\mathrm{ab}}$ & $1.62^{\mathrm{b}}$ & $1.43^{\mathrm{c}}$ & $1.61^{\mathrm{b}}$ & $1.90^{\mathrm{a}}$ & 0.08 \\
\hline $\begin{array}{l}\text { Kidney weight } \\
\text { (\%) }\end{array}$ & $0.32^{b}$ & $0.35^{\mathrm{b}}$ & $0.39^{b}$ & $0.39^{b}$ & $0.51^{\mathrm{a}}$ & 0.36 \\
\hline $\begin{array}{l}\text { Abdominal fat } \\
\text { weight }(\%)\end{array}$ & $1.22^{\mathrm{b}}$ & $2.08^{a}$ & $0.93^{b}$ & $0.78^{b}$ & $1.06^{\mathrm{b}}$ & 0.19 \\
\hline $\begin{array}{l}\text { Lungs weight } \\
(\%)\end{array}$ & $0.49^{b}$ & $0.58^{b}$ & $0.57^{b}$ & $0.64^{\mathrm{a}}$ & $0.64^{\mathrm{a}}$ & 0.03 \\
\hline Large intestine & $1.12^{\mathrm{b}}$ & $0.73^{b}$ & $1.06^{\mathrm{b}}$ & $1.35^{\mathrm{a}}$ & $1.40^{\mathrm{a}}$ & 0.13 \\
\hline
\end{tabular}


International Journal of Agriculture and Environmental Research

ISSN: 2455-6939

Volume: 07, Issue: 01 "January-February 2021"

weight $(\%)$

Small intestine

$42.68^{\mathrm{b}}$

$36.73^{\mathrm{b}}$

$47.72^{\mathrm{a}}$

$47.42^{\mathrm{a}}$

$47.96^{\mathrm{a}}$

1.45

weight $(\%)$

$\overline{a, b, c}$ Means on the same row with different superscripts are significantly $(\mathrm{P}<0.05)$ different.SEM= Standard Error of the Mean.

The significance $(\mathrm{p}<0.05)$ differences observed in this study on dressed weight was in support with (19) who observed heavier dressing percentage weight in the broilers treated with antibiotic than other groups treated with aloe vera 'gel except for the $2 \%$ Aloe vera gel group. There is decrease in eviscerated weight by oral supplementation of alovera gel. The heavier dressing weight value was experienced more in the control and vitalyte groups. This findings did not favour the earlier reports of (24) who stated that supplementation of fresh Aloe vera gel (0.25 $\mathrm{g} / \mathrm{kg})$ and dry Aloe vera gel $(0.25$ and $1.0 \mathrm{~g} / \mathrm{kg})$ in broiler diet from 1-day old to 5 weeks of age showed no significant effect on carcass yield and internal organs. On the contrary, (25) reported higher (55 percent) dressing percentage, breast, and thigh and giblet weight in broilers fed diet containing 0.5 percent turmeric and aloe vera. Abdominal fat deposition showed a reduction in weight as percentage of aloe vera gel increases. This was in support of (19) who found the same result on administration of aloe vera to broiler chicken and use of antibiotics. Other organs like head, gizzard, and empty gizzards, were found to be heavier in AVGE groups. The significant $(p<0.05)$ difference observed in $20 \%$ AVGE group with other groups in shank weight suggest that the absorption of calcium in aloe vera may be best in this inclusion.

The heavier heart observed in T4 and heavier liver and kidney weight also observed in T5 respectively in this recent research disagree with (43), who reported that, medicinal plant usage have been associated with tissue damage and serum enzyme alterations. The heavier lung, lengthy and heavier large intestine in T4 and T5 showed that all organs performed well due to anti-microbial nature of aloe vera which may have prevented any harmful effect to these organs. An increase in the relative weight of Gizzard and other internal organs of birds on T3, T4 and T5 may be associated with fact that there is always nutrient in balance when plant extracts are fed to animals. Again the internal organs like kidneys and liver are known as the primary recipient of any medicinal herbs or products before it is being absorbed in the body. This finding however did not agree with (44) and (45) who reported no effect of feeding herbal extracts on intestinal weight.

\section{CONCLUSION}

The results obtained in the present study showed that oral administration of aloe vera gel extract supplement to broiler finishers enhanced their growth performance, especially at the $30 \%$ 
inclusion level (1.2litre of AVGE +4 litres of water). The $30 \%$ inclusion level had higher value of final body weight $(3.41 \mathrm{~kg})$, lower value of feed conversion ratio (3.26) and low value of cost per kg gain ( 423.80k).

\section{ACKNOWLEDGEMENT}

The authors wish to acknowledge the Department of Animal Science, University of Nigeria, Nsukka Campus for making available the facilities for this research work.

\section{CONFLICT OF INTEREST}

The authors declare no conflict of interest

\section{REFERENCES}

1) Smith, A.J. Poultry. The Tropical Agriculture. $2^{\text {nd }}$ (revised) ed. Macmillan education ltd.U.K. 2001:Pp1-73.

2) Ani, A.O and Okeke, G.C. The performance of broiler birds fed varying dietary levels of roasted pigeon pea (cajanius cajann) seed meal. Pakistan Journal of Nutrition. 10(11): 2011:1036-1040.

3) Okoli, I.C., C.S. Ebere, O.O. Emenalom, M.C. Uchegbu and B.O. Esonu,. Indigenous livestock production paradigms revisited. III: An assessment of the proximate values of most preferred indigenous browses of South Eastern Nigeria. Trop. Anim. Prod. Invest, 2001: 4: 99-107.

4) Essien, J.P.; Ebong, G.A. and Akpan, E.J. Antioxidant and Antitussive Properties of Gongronema latifolium. J. Appl. Sci. Environ. Managt. 2007: 11(4): 47-50.

5) Nworgu F C, Ogungbenro S A and Solesi K S.. Performance and some blood chemistry indices of broiler chickens served fluted pumpkin (Telefaria occidentalis) leaves extract supplement. American-Eurasian Journal of Agriculture \& Environmental Sciencies, 2007: 2(1):90-9.

6) Galib A M A and Noor M W. Comparative study on diet supplementation with a mixture of herbal plants dandelion as a source of prebiotics on the performance of broilers. Pakistian journal of Nutrition; 2010: 9(1):67-71.

7) Jalal Bayati Zadeh, Nasroallah Moradi Kor. Component and Application Aloe Vera Plant in medicine. International journal of Advanced Biological and Biomedical Research; 2014: 2(5): 1876-1882.

8) Mehala, C., and Moorthy, M. Production Performance of Broilers Fed with Aloe vera and Curcuma longa (turmeric). International Journal of Poultry sciences; 2008:7(91:852-856). 
International Journal of Agriculture and Environmental Research

ISSN: 2455-6939

Volume: 07, Issue: 01 "January-February 2021"

9) Odo, B.I., Ekenyem B.U., and Nwamo, A.C. Effects of Alovera as leaf protein concentrates on Growth Performance of Cockerals. International Journal of Poultry science; 2010: 9(5) 426-428.

10) Muaz Ahmed and, FatmaHussain. Chemical Composition and Biochemical Activity of Aloe vera (Aloe barbadensis Miller) Leaves. IJCBS, 2013: 3:29-33.

11) Okonkwo, W.I. and Akubuo, C.O. Trombe wall system for poultry brooding. International Journal of Poultry sciences; 2007:6:125-130

12) Oluyemi, J. A. and F. A. Roberts. Poultry Production in Warm Wet Climates. 2000: $2^{\text {nd }}$ edition. Spectrum Books Ltd. Ibadan, Nigeria

13) AOAC. Association of Official Analytical Chemists. Official Methods of Analysis $\left(21^{\text {st }}\right.$ edition) Washington D.C. USA. 1990:2330.

14) Campbell, T.W. and Coles, E.H. Avian clinical pathology. In: Coles E.H (ed) Veterinary Clinical Pathology. $4^{\text {th }}$ edn. Saunders, Philadelphia; 1986: pp 279-291.

15) SPSS.Com.(2015).IBM ${ }^{(\mathrm{R})} \operatorname{SPSS}^{(\mathrm{R})}$ Advantage for Microsoft ${ }^{(\mathrm{R})} \mathrm{IBM}$. Corporation 2010,IBM Corporation Route,100,Somers, N4. 10589.

16) Duncan D B. Multiple Range and Multiple F-test. Biometrics, 1955:11:1-42

17) Adesuyi, A.O., Awosanya, O.A, Adaramola, F.B and Omeonu, A.I. Nutritional and Phytochemical Screening of Aloe barbadensis. Research of Journal Biological Science;2012:(1): 4-9, 2012ISSN: 2041-0778

18) Mahima, A. Rahal, R. Mandil, A.K. Verma and V. Kumar. Nutritional Potentials of Moringaolifera Leaves in Uttar Pradesh, India. Research Journal of Medicinal Plants; 2014: (8): 283-289.

19) Barbak Darabighane,1 Abolfazl Zarei,1 Ahmad Zare Shahneh,2 Ali Mahdavi. Effects of different levels of Aloe vera gel as an alternative to antibiotic on performance and ileum morphology in broilers. Italian Journal of Animal Science; 2011:10:36.

20) Olupona, J.A., Omotoso, O.R., Adeyeye, A.A., Kolawole, O.D., Airemionkhale, A.P., Adejinmi, O.O. Effect of aloe vera juice application through drinking water on performance, carcass characteristics, hematology and organoleptics properties in broilers. In: Proc. 98th Annual Meet. Poultry Science Association, Raleigh, NC, USA. 2010:pp 4243.

21) Hany Y Hassan, Magdy El-Sayed, Magda Ali Salah, Ahmed Zaghawa Magdy A, Aly .Efficacy Of Aloe Vera Gel Leaves For Treatment of Skin Affection Among Animals 1rst Ann. Confr ;2004: FVM, Moshtohor

22) Moorthy, M., Saravanan, S., Mehala, C, Ravi S. Ravikumar,, M., Viswanathan, K. and Edwin, S.C. Performance of single comb white leghorn layers fed with Aloe vera, Curcuma longa (turmeric) and probiotic. International Journal of Poultry sciences; 2009: 8(8): 775778. 
International Journal of Agriculture and Environmental Research

ISSN: 2455-6939

Volume: 07, Issue: 01 "January-February 2021"

23) Changkang, W., J. Hongqiang, T. Jianming, G. Weiwei, S. Renna and Z. Qi, Effect of Aloe powder and extract on production performance and immune function of broiler chickens. J. Fujian Agric. And Forestry Univ; 2005:36: 614-617.

24) Sinurat, A.P., Purwadaria, T., Togatorop, M.H., Pasaribu, I.A.K. Bintang, S. and Rosida, J. Responses of broilers to Aloe verabioactives as feed additive: the effect of different forms and levels of bioactives on performances of broilers. J. ILmu. Ternak. dan.Veteriner; 2002: 7: 69-75.

25) Durrani, F.R., Sanaullah, N. Chand, Z. Durrani and S. Akhtar. Using aqueous extract of aloe gel as anticoccidial and immunostimulant agent in broiler production. Sarhad J. Agric.;2008:24(4): 665-669

26) Ismail, M., F.R. Durrani, M. Amjad, S.M. Suhail and N. Chand. Effect of different levels of feed added Curcuma longa on overall performance of broiler chicks. J. Agric. and Bio. Sci. 1(2):1. Res; 2004: 2 (3): 2599-2606.

27) Mehmet C., G. Talat, B. Dalkilic and O. N. Ertas. The Effect of Anise Oil (Pimpinella anisum L.) on broiler performance. Int. J. Poult. Sci; 2005: 4 (11): 851-855

28) Madan, J., Sharma, A.K., Inamdar, N., Rao, H.S. and Singh, R. Immunomodulatory properties of Aloe vera gel in mice. Int. J. Green Pharma. 2008:2(3): 152-154.

29) Kamel, C. Tracing modes of action and the roles of plant extracts in non-ruminants. Pages 135-150 in Recent Advances in Animal Nutrition. P. C. Garnsworthy and J. Wiseman, ed. Nottingham University Press, Nottingham, UK

30) Wenk, C. Herbs, botanicals and other related substances; 2002:pp 1-10 in Proc. 11th Eur. Poultry Conf., Bremen, Germany

31) Biu, A.A., Yusuf, S.D and Rabo, J.S. Biochemical studies on the administration of aqueous leaf extract on neem (Azadiracthta indica A. Juss) in chicken. African scientist; 2010: vol 10.

32) Rabo, J.S., Onyeyili, P.A. and Khalil, M.I. Chronic toxicity of aqueous extract of Butyrospermum paradoxum stem bark in rabbits. Haematology and enzymology. Studies and Researches in Veterinary Medicine, Bucharest; 2003: 1:37-46

33) Avila H, Rivero J, Herrera F, Fraile G. Cytotoxicity of a low molecular weight fraction from Aloe vera (Aloe barbadensis Miller) gel. Toxicon; 1997; 35:1423-30.

34) Saka WA, Akhigbe RE, Popoola OT, Oyekunle os.Changes in serum electrolytes, urea, and creatinine in Aloe vera-treated rats. J Young Pharmacists ;2012; 4:78-81

35) Rajasekaran S, Ravi K, Sivagnanam K, Subramanian S. Beneficial effects of Aloe vera leaf gel extract on lipid profile status in rats with streptozotocin diabetes. Clin Exp Pharmacol Physiol; 2006; 33(3):232-7. doi: 10.1111/j.1440-1681.2006.04351. 
International Journal of Agriculture and Environmental Research

ISSN: 2455-6939

Volume: 07, Issue: 01 "January-February 2021"

36) Devaraj S, Yimam M, Brownell LA, Jialal I, Singh S, Jia Q.Effects of Aloe vera supplementation in subjects with prediabetes/metabolic syndrome. Metab Syndr Relat Disord. (2013); 11(1):35-40.

37) Kim K, Kim H, Kwon J, Lee S, Kong H, Im S-A,. Hypoglycemic and hypolipidemic effects of processed Aloe vera gel in a mouse model of non-insulin-dependent diabetes mellitus. Phytomedicine. 2009; 16(9):856-63.

38) Gebremedhin Y. Review on Medicinal Value of Aloe Vera in Veterinary Practice. Biomed J Sci \& Tech Res 6(1) - (2018).BJSTR. MS.ID.001287. DOI: 10.26717/ BJSTR.2018.06.001287

39) Koo M. Aloe vera: Antiulcer and antidiabetic effects. Phytother Res. 1994; 8(8):461-4. doi: 10.1002/ptr.2650080805

40) Yeh GY, Eisenberg DM, Kaptchuk TJ, Phillips RS. Systematic review of herbs and dietary supplements for glycemic control in diabetes. Diabetes Care.2003; 26(4):1277-94. doi: 10.2337/diacare.26.4.1277

41) Tanaka M, Misawa E, Ito Y, Habara N, Nomaguchi K, Yamada M, et al. Identification of five phytosterols from Aloe vera gel as anti-diabetic compounds. Biol Pharm Bull. 2006; 29(7):1418-22. doi: 10.1248/bpb.29.1418

42) Singh J, Koley KM, Chandrakar K and Pagrut NS. Effects of aloe vera on dressing percentage and haemato-biochemidal parameters of broiler chickens, Veterinary World; 2013: 6(10):803-806.

43) Sadre, N.L., Deshpande, V.Y., Mendulkar, K.N. and, Nandal, D.H. Male anti-fertility activity of Azadirachta indica A. Juss (Neem) in different species. 1984:Pp. 473 - 482. In: Schmutterer, H. and Ascher, K. R. S. eds. Natural pesticides from the neem tree (Azadirachta indica. A. Juss) and other tropical plants.1st ed. pp. 103- 114 CRC Press, Boca Raton, Florida, U.S.A. 1984.

44) Guo, F.C., R.P. Kwakkel, J.Soede, B.A. Williams and M.W. Verstegen. Effect of a Chinese herb medicine formulation, as an alternative for antibiotics, on performance of broilers. Brit. Poult. Sci.2004: 45(6):793-797.

45) Hernandez, F., J. Madrid, V. Garcia, J.Orengo and M.D. Megias. Influence of two plant extract on broiler performance; 2004. 